\title{
PEMBERDAYAAN MASYARAKAT DUSUN GUMAWANG MELALUI PENDAMPINGAN IJIN P-IRT
}

\author{
Oleh : \\ Isana Arum Primasari dan mahasiswa KKN Reguler PPM devisi 1.B.2 \\ Universitas Ahmad Dahlan Yogyakarta \\ E-mail: i_prisa@yahoo.com
}

\section{Ringkasan}

Salah satu permasalahan yang ada di masyarakat Dusun Gumawang, Desa Putat, Kecamatan Patuk, Kabupaten Gunungkidul, D.I. Yogyakrta adalah belum didapatkannya sertifikat P-IRT (Pangan Industri Rumah Tangga). Maka program KKN UAD difokuskan pada kebersihan lingkungan. Program ini bertujuan memberdayakan masyarakat Dusun Gumawang melalui pendampingan ijin P-IRT. Metode pelaksanaan program KKN meliputi: pendidikan masyarakat, difusi teknologi dan praktek langsung. Dampak dari kegiatan KKN ini adalah pelaku usaha mendapatkan setifikat ijin P-IRT yaitu No. P-IRT yang dapat dicantumkan pada poduk sehingga konsumen merasa aman untuk mengkonsumsi produk tersebut dan para pelaku usaha dapat lebih mengembangkan produknya dengan meningkatkan produksi dan pemasaran produk mereka.

Kata Kunci: Pemberdayaan,Pendampingan, Gumawang, P-IRT

\begin{abstract}
Abstrak
One of the problems that exist in the community Dusun Gumawang, Putat Village, District Patuk, Gunungkidul, D.I. Yogyakrta is the absence of P-IRT certificate (Food Industry Household). So UAD's KKN program is focused on environmental cleanliness. This program aims to empower the people of Hamlet Gumawang through the assistance of P-IRT permit. Methods of KKN program implementation include: community education, technological diffusion and direct practice. The impact of this KKN activity is the business actor obtaining the license of P-IRT license no. P-IRT that can be listed on the poduk so that consumers feel safe to consume these products and business actors can further develop their products by increasing the production and marketing of their products.
\end{abstract}

Keywords: Empowerment, Assistance, Gumawang, P-IRT

\section{A. PENDAhUluan}

Dusun Gumawang merupakan salah satu dusun dari desa Putat. Desa Putat terdiri dari 9 dusun, yaitu dusun Batur, dusun Bobung, dusun Gumawang, dusun Kepil, dusun Plumbungan, dusun Putat I, dusun Putat II, dusun Putat Wetan, dan Dusun Sendangsari. Dusun Gumawang merupakan dusun dengan sektor pertanian, perkebunan dan salah satu desa penghasil kakao di provinsi Daerah Istimewa Yogyakarta. Visi dusun Gumawang adalah penyelenggaraan pemerintah ditingkat padukuhan.

Dusun Gumawang dibagi menjadi 4 Rukun Tetangga (RT), diantaranya RT 22, 23, 24, dan 25. Dusun Gumawang ditempati oleh sekitar 510 jiwa dengan jumlah 149 KK.

Dusun Gumawang merupakan salah satu desa penghasil kakao di provinsi Daerah Istimewa Yogyakarta (DIY). Kakao yang dihasilkan dusun ini mempunyai kualitas baik dan jumlahnya melimpah. Selama ini, petani-petani kakao di Dusun Gumawang hanya menjual kakaonya pada perusahaan-perusahaan yang mengolah produk coklat seperti coklat Monggo dan nDalem. Apabila harga kakao menurun maka petani-petani akan 
merugi dan petani tidak mampu menawar biji kakao dengan harga lebih baik. Kondisi tersebut membuat perekonomian warga belum dapat ditingkatkan karena warga hanya bergantung pada penjualan biji kakao saja. Warga menyadari bahwa untuk meningkatkan perekonomian dusun dapat dilakukan dengan menambah nilai biji kakao melalui pengolahan biji kakao. Oleh karena itu, warga mempunyai inisiatif untuk memperbaiki perekonomiannya dengan mengolah produk olahan coklat secara mandiri.

Saat ini, ibu-ibu di Dusun Gumawang telah menjalankan sebuah unit usaha yang memanfaatkan kakao tersebut. Produk dari unit usaha ini adalah dodol kakao dan coklat berisi dodol. Berbekal pengetahuan mengenai produk olahan coklat yang didapatkan dari pelatihan Dinas Perindustrian DIY, ibu-ibu tersebut memproduksi berbagai olahan dari kakao seperti dodol kakao dan coklat isi dodol yang sudah berjalan sampai sekarang. Tetapi usaha itu menemui kendala dalam hal pemasaran yang disebabkan belum didapatkannya sertifikat P-IRT (Pangan Industri Rumah Tangga). Kendala ini membuat pemasaran produk tidak dapat dilakukan di toko-toko, swalayan, dan tempat penjualan resmi lainnya. Permasalahan sertifikat merupakan masalah utama unit usaha ini, yang menjadikan produk mereka belum dapat memberikan nilai tambah yang signifikan bagi perekonomian warga. Di sisi lain, dusun memiliki bahan baku utama yang berkualitas tinggi dan melimpah.

Berdasarkan permasalahan tersebut, maka ditetapkan tujuan program KKN ini adalah memberdayakan masyarakat gumawang melalui pendampingan ijin P-IRT.

\section{B. METODE PELAKSANAAN}

Untuk mencapai tujuan yang diharapkan, program KKN PPM di Dusun Gumaang dilakukan dengan pemberdayaan masyarakat melalui pendidikan masyarakat, difusi ilmu pengetahuan dan teknologi dan praktek langsung. Ringkasan metode pelaksanaan beserta jam kerja efektif mahasiswa (JKEM) tersaji pada table.

\begin{tabular}{|l|l|l|l|c|}
\hline No & \multicolumn{1}{|c|}{ Metode } & \multicolumn{1}{|c|}{ Kegiatan } & $\begin{array}{c}\text { Mahasiswa } \\
\text { yang Terlibat }\end{array}$ \\
\hline 1 & Pendidikan Masyarakat & $\begin{array}{l}\text { Penyelenggaraan } \\
\text { Pelatihan Proses } \\
\text { Produks yang } \\
\text { baik }\end{array}$ & $5 \times 100 "$ & 9 \\
\cline { 2 - 5 } & $\begin{array}{l}\text { Penyelenggaraan } \\
\text { Penyuluhan } \\
\text { tentang } \\
\text { pengolahan } \\
\text { makanan yang } \\
\text { baik }\end{array}$ & $\begin{array}{l}\text { (x) 100" } \\
\text { Pelatihan } \\
\text { manajemen } \\
\text { sumber daya } \\
\text { manusia }\end{array}$ & 9 \\
\hline 2 & Difusu Iptek & $\begin{array}{l}\text { Penyelenggaraan } \\
\text { pelatihan }\end{array}$ & $4 \times 200 "$ & 9 \\
\hline
\end{tabular}


Diterbitkan oleh Lembaga Pengabdian kepada Masyarakat

Universitas Ahmad Dahlan Yogyakarta

\begin{tabular}{|l|l|l|l|c|}
\hline & $\begin{array}{l}\text { pengemasan } \\
\text { produk }\end{array}$ & \\
\hline & $\begin{array}{l}\text { Penyelenggaraan } \\
\text { pelatihan } \\
\text { pemasaran } \\
\text { produk }\end{array}$ & $3 \times 200 "$ & 9 \\
\hline 3 & Praktek & $\begin{array}{l}\text { Penyelenggaraan } \\
\text { Pelatihan } \\
\text { Pembuatan } \\
\text { Coklat }\end{array}$ & $5 \times 200$ & \\
\hline \multirow{2}{*}{} & $\begin{array}{l}\text { Penyelenggaraan } \\
\text { pelatihan } \\
\text { diversifikasi } \\
\text { Coklat }\end{array}$ & $3 \times 200 "$ & \\
\hline & $\begin{array}{l}\text { Penyelenggaraan } \\
\text { Pendampinan } \\
\text { pengurusan ijin } \\
\text { PIRT }\end{array}$ & & \\
\hline & & & \\
\hline
\end{tabular}

\section{HASIL,PEMBAHSAN, DAN DAMPAK}

\section{Profil Dusun Gumawang}

Desa Putat terdiri dari 9 dusun, yaitu dusun Batur, dusun Bobung, dusun Gumawang, dusun Kepil, dusun Plumbungan, dusun Putat I, dusun Putat II, dusun Putat Wetan, dan Dusun Sendangsari. Dusun Gumawang merupakan dusun dengan sektor pertanian, perkebunan dan salah satu desa penghasil kakao di provinsi Daerah Istimewa Yogyakarta. Visi dusun Gumawang adalah penyelenggaraan pemerintah ditingkat padukuhan.

Luas wilayah dusun Gumawang yaitu 75.9342 Ha. Dusun Gumawang dibagi menjadi 4 Rukun Tetangga (RT), diantaranya RT 22, 23, 24, dan 25. Dusun Gumawang ditempati oleh sekitar 510 jiwa dengan jumlah 149 KK. Penduduk laki-laki berjumlah 265 jiwa dan penduduk perempuan berjumlah 243 jiwa.

Mata pencarian sebagian besar petani, peternak, pekebun dan wiraswasta. Masyarakat dusun Gumawang memiliki potensi dalam berbagai bidang yang dapat meningkatkan perekonomian masyarakatnya. Di Dusun Gumawang terdapat 3 industri kecil dan 5 industri Rumah Tangga.

Potensi tersebut antara lain:

\begin{tabular}{|l|l|l|l|}
\hline No & Bidang Usaha & Jenis & Produk \\
\hline 1 & \multirow{2}{*}{ Kerajinan } & Kayu & Meubel, topeng, souvenir \\
\cline { 3 - 4 } & & Bambu & Besek \\
\hline
\end{tabular}




\begin{tabular}{|l|l|l|l|}
\hline 2 & Makanan & Pangan olahan & $\begin{array}{l}\text { Dodol coklat, coklat isi dodol, } \\
\text { minuman daun coklat }\end{array}$ \\
\cline { 3 - 4 } & Pangan lokal & $\begin{array}{l}\text { Keripik rempeyek, telur asin, } \\
\text { keripik tempe, keripik singkong, } \\
\text { susu kedelai }\end{array}$ \\
\hline 3 & Industri & Daur ulang sampah & \\
\hline 4 & Pertanian & Padi, Palawija & \\
\hline 5 & Perkebunan & Kakao & $\begin{array}{l}\text { Ayam, Burung Puyuh, } \\
\text { Kambing, Sapi }\end{array}$ \\
\hline 6 & Peternakan & Gamelan, toklek, jatilan & \\
\hline 7 & Kesenian & & \\
\hline
\end{tabular}

\section{Gambaran Pelaksanaan}

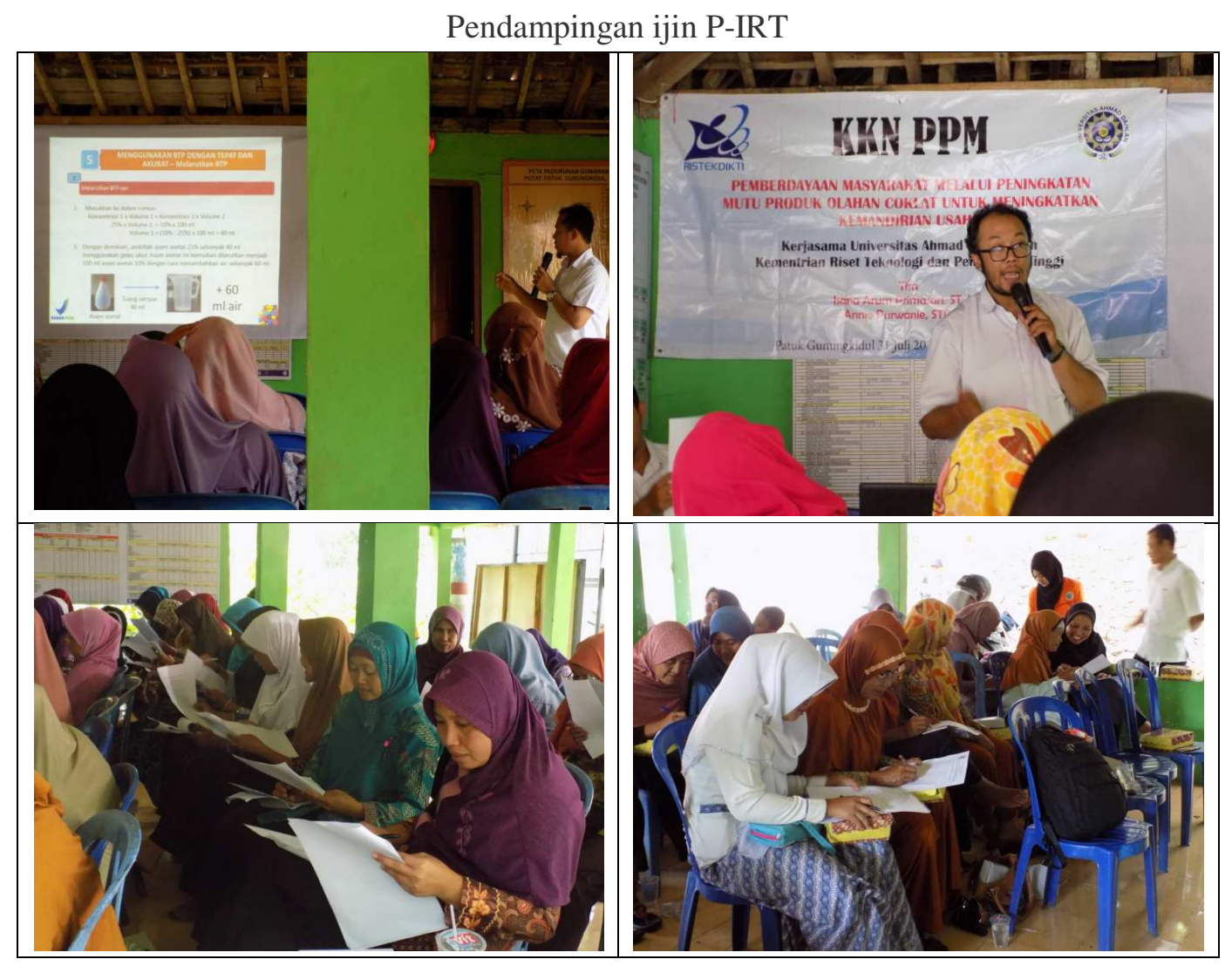

Gambar IV

Program pendampingan ijin P-IRT dilaksanakan pada tanggal 16 dan 18 Agustus 2016 yang bertempat di Balai Dusun Gumawang. Pendampingan dilakukan oleh 2 orang tim pengusung program bersama 27 mahasiswa KKN serta 8 orang Staf dari Dinas Kesehatan Gunungkidul. Pendampingan pengurusan iijin PIRT ini diikuti oleh para pelaku usaha yang ada di Gumawang, Plumbungan dan Ploso Kerep. 
Diterbitkan oleh Lembaga Pengabdian kepada Masyarakat

Universitas Ahmad Dahlan Yogyakarta

Pada kegiatan pendampingan ijin P-IRT tersebut para pelaku usaha diberikan penyuluhan mengenai ijin P-IRT dan kemudian mengikuti Pra Test dan Post Test mengenai materi tersebut. Selanjutnya Dinas Kesehatan melakukan visitasi rumah produksi para Pelaku usaha pada tanggal 18. Pelaku usaha yang telah memenuhi persyaratan ijin P-IRT akan diberikan sertifikat ijin P-IRT oleh Dinas Kesehata Gunungkidul.

Dari gambar IV terlihat program KKN di Dusun Gumawang dapat terlaksana dengan partisipasi masyarakat yang cukup tinggi dengan kata lain dapat memperdayakan masyarakat dalam program-program yang telah direncanakan. Dampak dari kegiatan KKN ini adalah pelaku usaha mendapatkan setifikat ijin P-IRT yaitu No. P-IRT yang dapat dicantumkan pada poduk sehingga konsumen merasa aman untuk mengkonsumsi produk tersebut dan para pelaku usaha dapat lebih mengembangkan produknya dengan meningkatkan produksi dan pemasaran produk mereka.

\section{Daftar sertifikat ijin P-IRT}

\begin{tabular}{|l|l|l|l|}
\hline NO & \multicolumn{1}{|c|}{ JENIS PRODUKSI } & \multicolumn{1}{c|}{ MERK } & \multicolumn{1}{c|}{ NO P-IRT } \\
\hline 1 & Dodol Kakao & Dokagum & $2063403010507-21$ \\
\hline 2 & Telur Asin & Ibnu Rasa & $2033403020507-21$ \\
\hline 3 & Keripik Tempe & Fandy & $2153403030507-21$ \\
\hline 4 & Coklat Dodol & Cokladol Jas Orange & $2103403040507-21$ \\
\hline 5 & Keripik Singkong & Dua Daun & $2153403050507-21$ \\
\hline 6 & Rengginang Coklat & Choreng & $2153403060507-21$ \\
\hline 7 & Minuman Daun Kakao & Midako & $2133403070507-21$ \\
\hline 8 & Coklat Keripik Singkong & Chotello & $2153403080507-21$ \\
\hline 9 & Permen Coklat & Orangecho & $2103403090507-21$ \\
\hline
\end{tabular}

\section{KESIMPULAN}

Berdasarkan pelaksanaan kegiatan ini, Program KKN UAD dalam memberdayakan masyarakat Dusun Gumawang melalui pendampingan ijin P-IRT berjalan dengan baik dan berdampak baik bagi masyarakat Dusun Gumawang khususnya para pelaku usaha.

\section{DAFTAR PUSTAKA}

Dinas Kesehatan Gunungkidul, Pengurusan ijin P-IRT, 2017

Sistem Informasi Desa Putat, 2017.

https://lpm.uad.ac.id/pendampingan-usaha-produk-olahan-coklat-di-dusun-gumawangpathuk-kabupaten-gunung-kidul-guna-mendapatkan-sertifikat-p-irt 
